\title{
MJERENJE DEPRESIVNOSTI U POSTUPKU PROCJENE RADNE SPOSOBNOSTI: PSIHOMETRIJSKA OBILJEŽJA SKALE DEPRESIJE D-92
}

\author{
Ljerka Hajncl \\ Zavod za vještačenje, profesionalnu rehabilitaciju i zapošljavanje osoba s invaliditetom \\ Područni ured Osijek \\ Tadije Smičiklasa 2, 31000 0sijek \\ ljerka.hajnc1@os.ht.hr \\ Vladimir Kolesarić \\ Filozofski fakultet Zagreb \\ Ivana Lučića 3, 10000 Zagreb \\ vkolesar@ffzg.hr \\ Dario Vučenović \\ Hrvatski studiji Sveučilišta u Zagrebu \\ Borongajska cesta 83d, 10000, Zagreb \\ dvucenovi@hrstud.hr
}

\begin{abstract}
Sažetak
Skala depresije D-92 (Krizmanić i Kolesarić, 1994) izvorni je hrvatski psihologijski instrument za mjerenje intenziteta simptoma depresivnosti u kliničkoj populaciji odraslih. Oslanjajući se na Beckovu teoriju nastanka i održavanja simptoma depresije, u skalu su uključene čestice kojim se ispituje odnos ispitanika prema sebi, prema drugim ljudima i prema budućnosti. U ovom radu provjerena je osjetljivost, pouzdanost, konvergentna i divergentna valjanost te sposobnost D-92 skale da diferencira ispitanike unutar klinički dijagnosticiranih skupina s depresivnim poremećajem, anksioznim poremećajima i drugim duševnim poremećajima. Ispitivanje je provedeno na prigodnom uzorku od 210 klinički dijagnosticiranih ispitanika s depresivnim, anksioznim poremećajem i drugim duševnim poremećajima pri procjeni radne sposobnosti. Ispitanici su popunjavali test kognitivnih sposobnosti, Crown-Crispov indeks iskustava i skalu depresije D-92. Rezultati istraživanja upućuju na vrlo dobru osjetljivost skale da razlikuje osobe prema broju i intenzitetu simptoma depresije u odabranom kliničkom uzorku u situaciji procjene radne sposobnosti $(\mathrm{SD}=9,70)$. Unutrašnja konzistencija ( $\alpha$ $=0,89$ ) upućuje na zadovoljavajuću pouzdanost skale D-92. Konvergentna valjanost skale podržana je visokom korelacijom sa subskalom depresivnosti u CCII upitniku $(r=0,62)$. U korist divergentnoj valjanosti ne ide visoka korelacija s mjerama generalizirane anksioznosti $(r=0,62)$ i somatizirane anksioznosti $(r=0,55)$ na CCII upit-
\end{abstract}


niku. Univarijatna analiza varijance razlika u obilježju depresivnosti između skupina $\mathrm{s}$ različitim bolestima upućuje na to da je intersekcija raspodjele rezultata visoka pa ispitanici mogu pripadati u sve skupine bolesti.

Ključne riječi: procjena radne sposobnosti, skala depresije D-92, psihometrijske karakteristike

\section{UVOD}

Depresija je duševni poremećaj čija su bitna obilježja pretežito tužno raspoloženje veći dio dana, bezvoljnost, osjećaj bezvrijednosti i beznađa (Kaplan i Sadock, 1998, Hautzinger, 2009). Depresiju određuju kognitivni, motivacijski, emocionalni, somatski i bihevioralni kriteriji (Vulić-Prtorić, 2004). Kognitivni kriteriji su negativna pristranost u pogledu budućnosti, interpretacija budućih događaja kao sigurnih neuspjeha, izvora frustracija i nezadovoljstva. Motivacijski kriteriji su odustajanje i gubitak volje za aktivnosti, pesimistička predviđanja osoba da neće uspjeti u novim zadacima i da njihovi najteži problemi nikada neće biti riješeni (Novović, Gavrilov, Tovilović, i Biro, 2005). Emocionalne kriterije čine negativna čuvstva tuge, raspoloženja obeshrabrenosti i beznađa. Somatski simptomi su promjene u tjelesnoj težini, promjene apetita, poremećen ritam spavanja, a bihevioralni simptomi psihomotorni nemir ili zakočenost, usporen govor i pokreti tijela (Hautzinger, 2009). Depresivne osobe jednostavno se mogu opisati kao obeshrabrene, tihe, bez energije i beznadne (Groth-Marnat, 2003).

Na konceptualnoj razini depresija se određuje specifičnim obilježjima i ponašanjima iz različitih teoretskih modela poput dijateza-stres modela (Meehl, 1962), Beckova modela depresije (Beck, 1970) i sl. Kako će se depresija odrediti i mjeriti, ima izravne posljedice za rano otkrivanje depresivnosti, za proces formiranja prediktivnih hipoteza i donošenje odluka o liječenju i sposobnosti radnog ili izvršnog funkcioniranja depresivnih osoba. Rano otkrivanje depresije, razlikovanje bolesnika s kliničkom depresijom od bolesnika bez depresije, razlikovanje depresije od srodnih poremećaja kao i otkrivanje poremećaja u nastajanju jednako je važno na konceptualnoj kao i razini operacionalizacije. Razvojem i validacijom mjernih instrumenata omogućuje se adekvatna i kulturalno osjetljiva operacionalizacija ovog heterogenog sindroma.

\section{Psihološka procjena depresivnosti}

Minimalni standard za dijagnosticiranje depresivnog poremećaja obuhvaća postavljanje dijagnoze i diferencijalna dijagnoza koja se pretpostavlja nakon provedenog kliničkog strukturiranog intervjua i podržava psihometrijskom procjenom težine poremećaja primjenom upitnika depresivnosti bilo u obliku samoprocjene, kao npr. kod Beckova inventara depresije ili/i procjenom od strane drugih osoba, 
npr. Hamiltonove ljestvice depresije (Hautzinger, 2009). U kliničkoj psihologiji upitnici su konstruirani za mjerenje razine klinički relevantnih depresivnih simptoma za različite dobne skupine. Postoje skale depresivnosti kod djece i adolescenata (Kovacs, 1981; Beck, Beck, Jolly i Steer, 2011; Vulić-Prtorić, 2003), zatim za ispitivanje depresivnih simptoma kod odraslih (Zung, 1965; Hamilton, 1960; Rush i sur., 1986; Beck, Steer i Brown, 1996; Krizmanić i Kolesarić, 1994, Beck, Steer, i Brown, 2009) i upitnici za utvrđivanje razine depresivnosti starih osoba (Yesavage i sur., 1982). Depresivnost se osim toga ispituje na kliničkim skalama u inventarima ličnosti poput Millon kliničkog multifazičnog upitnika (MCMI) za odrasle (Millon, 1977) ili Minnesota multifazičnog upitnika ličnosti (Hathaway i McKinley, 1943), njegove novije verzije MMPI ${ }^{\circledR}-2$ (Butcher i Williams, 1999) ili trijažnim inventarima poput Crown-Crispova indeksa iskustava (Crown i Crisp, 1994).

Upitnicima se nastoji utvrditi postoji li i u kojoj mjeri kognitivna dimenzija poremećaja, somatsko-vegetativna dimenzija, dimenzija raspoloženja, a većina dopušta ukupnu mjeru depresivne simptomatologije u cjelini. Krizmanić i Kolesarić (1994) navode da se upitnici razlikuju po sadržaju i broju pitanja te načinu vrednovanja odgovora. Sadržaj pitanja ili tvrdnji koje se u upitnicima koriste najčešće je vezan za neku teoriju ličnosti, npr. Beckov upitnik depresije, petofaktorski upitnici ličnosti i sl. ili se osniva na kliničkim klasifikacijama simptoma različitih poremećaja kao što su skale depresivnosti na MCMI i MMPI. Nedostaci skala pojavljuju se u slučajevima kada se zbog potreba teorije izbacuju pojedina obilježja depresije pa se gubi veza s kriterijima klasifikacije za depresivnu epizodu (Novović, Mihić, Tovilović, Jovanović i Biro, 2011). Formalni nedostaci proizlaze iz načina oblikovanja pitanja, rasporeda pitanja, razumljivosti pitanja i načina bodovanja odgovora. Dodatni faktor koji utječe na valjanost odgovora na upitniku je utjecaj mogućih subjektivnih momenata iskrivljavanja odgovora ispitanika. Da bi se prevladali neki nedostaci postojećih upitnika konstruiraju se nove i revidiraju postojeće skale depresivnosti. U svrhu poboljšanja mjerenja provode se istraživanja psihometrijskih svojstava upitnika depresije na specifičnim uzorcima, za različite svrhe procjene i u različitim kulturološkim kontekstima.

\section{Skala depresije D-92}

Jedan od izvornih hrvatskih instrumenata za mjerenje depresivnosti odraslih je skala depresije D-92. Autori Krizmanić i Kolesarić (1994) navode da je skala D-92 razvijena kao normalnoj populaciji primjeren psihodijagnostički instrument za mjerenje konstrukta depresivnosti. Test nije namijenjen dijagnosticiranju depresivnosti, nego procjeni težine klinički dijagnosticirane skupine. Priklanjajući se istraživačima koji zagovaraju dimenzionalno stajalište psihopatoloških entiteta (Waller i Meehl, 1998), autori D-92 skale depresiju smještaju na kontinuumu od normalne, povremene i prolazne žalosti do duboke depresije koja traje ili se stalno 
ponovo vraća. Autori skale operacionalizirali su konstrukt depresivnosti kao prolazno, trajnije ili trajno stanje, koje izaziva niz promjena u doživljavanju i izražavanju čuvstava, kognitivnim procesima, zadovoljavanju osnovnih životnih potreba kao što je spavanje, ishrana, aktivitet, spolnost i ponašanja. U skalu D-92 uključeni su simptomi depresije koji se najčešće spominju u stručnoj literaturi i nalaze u upitnicima i skalama depresivnosti, a pokrivaju širok raspon različitih oblika doživljavanja i ponašanja karakterističnih za depresiju (Krizmanić i Kolesarić, 1994). Autori navode da je skala konstruirana za praktične i istraživačke svrhe. Oslanjajući se na Beckovu teoriju nastanka i održavanja simptoma depresije (Beck, 1970), u skali su uključena pitanja koja ispituju odnos ispitanika prema sebi, prema drugim ljudima i prema budućnosti. Svrha je skale kod pojedinca ispitati čuvstveno doživljavanje (Prevladava li u posljednje vrijeme i kod vas tuga i žalost nad radošću i veseljem?), ponašanje (Primjećujete li da ste u posljednje vrijeme više skloni plaču (plačljiviji) nego što je to za vas uobičajeno?) i kognitivne promjene potaknute depresivnošću (Jeste li u posljednje vrijeme kod sebe primijetili da se ni na što ne možete odlučiti?). Skala D-92 konstruirana je sa svrhom da se izbjegnu neki nedostaci do tada postojećih skala depresije. Načinom prezentacije pitanja i određivanjem vremena za koje osoba procjenjuje postojanje simptoma smanjuju se efekti zaboravljanja pitanja, a opisivanjem različitih doživljavanja i ponašanja kao svakodnevnih ljudskih reakcija, nastoje se smanjiti efekti socijalno poželjnog ili/i neiskrenog odgovaranja na valjanost dobivenog rezultata.

\section{Valjanost Skale D-92}

Broj faktora koji su se u istraživanju mogli ekstrahirati faktorskom analizom iz procjena ispitanih uzoraka studenata i oboljelih, upućivao je na to da je depresivnost kao sindrom heterogen, te da je može odrediti više dimenzija poput poremećaja raspoloženja i promjena u ponašanju. Faktorskom analizom nerotiranih faktora izlučenih metodom glavnih komponenata utvrđen je multidimenzionalni konstrukt depresivnosti - 46,8\% varijance četiri faktora, a sva četiri su opterećena prvim faktorom, čime su potvrđene pretpostavke o depresiji kao relativno heterogenom entitetu. Na skupini depresivnih dobiveno je sedam faktora koji zaokupljaju 71\% varijance, a prvi faktor depresivnosti dominira i sam pokriva $31,8 \%$ varijance (Krizmanić i Kolesarić, 1994).

$\mathrm{U}$ manjem broju dosadašnjih ispitivanja u kojim se provjeravala vrijednosti skale D-92 potvrđena je sposobnost skale da razlikuje depresivne od nedepresivnih ispitanika. Diskriminacijskom analizom utvrđena je vrijednost Wilksove lambde 1, što pokazuje da test može dobro diskriminirati depresivne od nedepresivnih osoba (Krizmanić i Kolesarić, 1994, Feöcze, 1994). Nadalje, do sada je potvrđena konvergentna valjanost skale (Proroković, Zelić i Vulić-Prtorić, 2004, Tomica, 2009). Ispitujući povezanost ukupnog rezultata na Skali depresivnosti D-92 primijenjenog 
na hrvatskom uzorku dobivena je visoka pozitivna korelacija s rezultatima na Upitniku automatskih misli - ATQ ( $\mathrm{r}=0,80, r=0,58$ i $r=0,86$; Proroković i sur., 2004). Također je utvrđena pozitivna povezanost s rezultatom na Beckovoj skali depresivnosti BDI-II na uzorku adolescenata $(\mathrm{r}=0,74)$ (Tomica, 2009).

Veći broj istraživanja je potreban da se ispitaju psihometrijska svojstva D-92 skale. Do sada nije provedeno istraživanje koje bi pokazalo koje su psihometrijske vrijednosti skale D-92 na kliničkom uzorku ispitanika u situaciji procjene radne sposobnosti, u kojem je važno otkriti mogu li se razlikovati ispitanici međusobno prilikom procjene radne sposobnosti po intenzitetu depresivnosti, te postoji li razlika u visini depresivnosti po rezultatu na skali D-92 u skupinama osoba s dijagnozom depresivnog, anksioznog i drugih duševnih poremećaja u kontekstu procjene radne sposobnosti. Očekuje se da će skala D-92 kao mjera depresivnosti imati zadovoljavajuću osjetljivost, pouzdanost i valjanost za utvrđivanje depresivnih simptoma ispitanika u kontekstu procjene radne sposobnosti kao i da će ispitanici oboljeli od depresivnog poremećaja imati više rezultate na D-92 skali depresije od ispitanika iz skupina oboljelih od anksioznog i drugih duševnih poremećaja u situaciji procjene radne sposobnosti.

\section{METODA}

\section{Sudionici}

Ispitivanje je provedeno na uzorku ispitanika od $\mathrm{N}=210(127$ muškaraca $\mathrm{i}$ 93 žene) s depresivnim, anksioznim i drugim duševnim poremećajima, koji su u postupku procjene radne sposobnosti pristupili psihologijskom ispitivanju. Svrha psihologijskog ispitivanja bila je utvrditi utječe li depresivnost $i$ anksioznost $u$ okviru različitih duševnih poremećaja na promjene u radnoj sposobnosti oboljele osobe. Odabrani su ispitanici kojima je u okviru psihijatrijskog liječenja klinički dijagnosticiran depresivni poremećaj, anksiozni poremećaj, a treću skupinu činili su ispitanici koji su iskazivali depresivnost i anksioznost u kliničkoj slici, a koji su u povijesti bolesti imali dijagnozu alkoholizam u apstinenciji i psihotičnosti u remisiji. Radi se o ispitanicima koji su s tim dijagnozama upućeni na vještačenje radne sposobnosti u razdoblju od dvije godine.

\section{Instrumenti}

Ispitanici su individualno popunjavali jedan od sljedećih testova opće mentalne sposobnosti: Obojene progresivne matrice, Purdue test neverbalnog zaključivanja, Kognitivno neverbalni test. Testovi inteligencije mijenjali su se sukladno zdravstvenim obilježjima, kognitivnim mogućnostima, razini obrazovanja ispitanika te eventualnoj prethodnoj upoznatosti ispitanika s testovima. 
Obojene progresivne matrice - CPM, (Raven, Court i Raven, 1994) namijenjene su za ispitivanje intelektualne sposobnosti koje se koriste u radu s ljudima i djecom koji zbog bilo kojeg razloga ne razumiju ili ne govore jezik, koji pate od tjelesnih, senzornih i govornih oštećenja, kao i s osobama s intelektualnim teškoćama. Test se sastoji od tri serije od 12 zadataka koji ispituju glavne kognitivne procese.

Za osobe bez takvih teškoća primijenjen je jedan od dva g-faktorska testa neverbalnog logičkog zaključivanja i to Kognitivno neverbalni test - KNT (Momirović i Sučević, 2004) koji se sastoji od 40 zadataka s crtežima geometrijskih oblika. Ispitanik treba izdvojiti i prekrižiti lik koji po svojoj perceptualnoj organizaciji ne pripada toj skupini likova. Kao alternativni test primijenjen je Purdue test neverbalnog logičkog zaključivanja (PNT), koji su konstruirali Tiffin, Gruber i Inaba 1958. godine (Matešić, 1994). Test se sastoji od 48 zadataka s crtežima geometrijskih oblika. Svaki zadatak sastoji se od 5 crteža, a ispitanik treba odrediti koji od tih 5 crteža je bitno drugačiji od ostala 4 i prekrižiti ga olovkom. Rezultat svakog ispitanika postignut $\mathrm{u}$ jednom od navedenih testova inteligencije standardiziran je $\mathrm{u} z$-vrijednosti.

Zatim su ispitanici popunili upitnike za procjenu anksioznih i depresivnih stanja: Crown-Crispov indeks iskustava CCII i Skalu depresije D-92.

Crown-Crispov indeks iskustava CCII (Crown i Crisp, 1994) trijažni je instrument za ispitivanje neurotizma, opće emocionalnosti i osobina ličnosti unutar konvencionalnih kategorija psihoneurotskih bolesti i poremećaja ličnosti. Upotrebljava se u svrhu trijažnih pregleda, pri praćenju promjena nastalih određenim terapijskim postupcima ili u istraživačke svrhe. Sadrži 48 čestica koja su razvrstane u šest subskala: slobodno lebdeća anksioznost (FFA) "Osjećate li se nemirno i zabrinuto", fobična anksioznost (PHO) "Bojite li se visine", opsesivnost (OBS) "Kažu li vam ikad da ste pretjerano savjesni", somatska manifestacija anksioznosti (SOM) "Patite li od vrtoglavice ili poteškoća s disanjem", depresija (DEP) "Kajete li se mnogo zbog svojih postupaka" i histerija (HYS) "Volite li biti u centru pažnje". Uz svaku česticu ispitanik treba označiti jedan od odgovora koji se odnosi na njega. Odgovor na neka pitanja ponuđen je $u$ dvije varijante, $u$ jednostavnoj alternativnoj formi dane, ili, kao jedan od tri predložena izbora: često - ponekad - nikad. Pitanja su pisana jednostavnim jezikom, što omogućuje korištenje indeksa na ispitanicima širokog raspona obrazovanja i intelektualnih sposobnosti. PHO ljestvica dobro utvrđuje stanja fobične anksioznosti. OBS - autori određuju kao korisno sredstvo identifikacije ispitanika koji pate od opsesivnih neuroza. SOM - ljestvica je pokazatelj tjelesnih tegoba kod ispitanika. DEP subskala dobar je pokazatelj depresivnih tegoba. HYS - je pokazatelj histerične ličnosti. Utvrđena pouzdanost subskala na CCII varirala je u zavisnosti od veličine uzorka, od vrste subskale i metode za utvrđivanje pouzdanosti. Najveća pouzdanost dobivena je na 129 industrijskih radnika metodom test - retest nakon godine dana $(\mathrm{FFA}=0,77, \mathrm{PHO}=0,68, \mathrm{OBS}=0,73, \mathrm{SOM}=0,68$, $\mathrm{DEP}=0,72$ i HYS $=0,72)($ Crown i Crisp, 1994).

Skala depresivnosti D-92 (Krizmanić i Kolesarić, 1994) namijenjena je za određivanje globalnog stupnja i mjerenju intenziteta simptoma depresivnosti kod oso- 
ba iznad 16 godina. Skala se može primjenjivati na uzorcima ispitanika različitog stupnja obrazovanja. U skali su u 22 čestice predložene kratke tvrdnje koje opisuju uobičajene načine doživljavanja i ponašanja većine ljudi. Iz tih tvrdnji od ispitanika se traži jedan od četiri predložena odgovora: A, B, C ili D. Predloženi odgovori svrstavaju se u četiri stupnja od pozitivnog do negativnog ekstrema. Sva četiri predložena odgovora uvijek se odnose samo na jedan simptom depresije (primjer tvrdnje i pitanja - varijanta za ženske ispitanike: Sigurno ste već primijetili da ima ljudi koji su gotovo stalno radosni i veseli i onih koji su gotovo stalno tužni i žalosni. Prevladava li u posljednje vrijeme $i$ kod vas tuga $i$ žalost nad radošću $i$ veseljem? A) - stalno sam vedra $i$ vesela, B) - uglavnom sam vedra $i$ vesela, C) - uglavnom sam tužna i žalosna, D) - stalno sam tužna i žalosna. Slično Zungovoj skali (Zung, 1965) i Beckovoj skali depresije II (Beck i sur., 2009), usmjeravanje ispitanika na opis vlastitih reakcija u "posljednje vrijeme" odabrano je s ciljem utvrđivanja simptoma koji nisu izazvani trenutačnim događajima ili situacijama, već traju barem dva tjedna, što je usklađeno s određenjem trajanja simptoma velike depresivne epizode. Predloženi odgovori dobivaju jedan ili dva boda kada ne upućuju na depresivnost, a tri ili četiri boda kada upućuju na postojanje depresivnosti. Ukupan rezultat na primijenjenoj skali dobiva se zbrajanjem bodova uz svaku tvrdnju prema ključu za odgovore i usporedbom s normama za pripadajući uzorak. Minimalni mogući rezultat iznosi 22 boda, a maksimalni 88 bodova. Osjetljivost skale za selekcionirani uzorak određena je totalnim rasponom i koeficijentom relativnog varijabiliteta.

Normativni podaci koje iznose autori pokazuju da je prosječan rezultat nedepresivnih ispitanika iznosio oko 44, sa standardnom devijacijom od 7 do 8 , dok su prosječni rezultati depresivnih ispitanika oko 62, sa standardnom devijacijom oko 10. Rezultati od 60 do 62 boda uzimaju se kao kritična granica za patološku izraženost depresivnih simptoma (Krizmanić i Kolesarić; 1994; Feöcze, 1994).

U različitim istraživanjima utvrđena je visoka razina pouzdanosti skale D-92, kako za nedepresivne $(\alpha=0,84)$ tako i za depresivne osobe $(\alpha=0,84)$ (Krizmanić i Kolesarić, 1994; Tomica, 2009). Visoka pouzdanost skale D-92 utvrđena je i na modificiranoj verziji skale za djecu $(\alpha=0,81)$ (Marinović i Vulić-Prtorić, 2000).

\section{REZULTATI}

Kako je vidljivo iz Tablice 1, skala depresivnosti D-92 na ukupnom kliničkom uzorku u situaciji procjene radne sposobnosti pokazala je vrlo dobru osjetljivost. Osjetljivost skale određena je rasponom ukupnog rezultata od 35 do $88(53,00)$, relativnim rasponom ukupnog rezultata $(0,80)$ te standardnom devijacijom $(9,70)$.

Također je izračunat Cronbach alpha, koji iznosi $(\alpha=0,89)$.

Skala indeksa iskustava CCII najveće raspršenje ima na skali fobičnosti (SD = $3,11)$, a najmanje na skali histerije ( $\mathrm{SD}=2,26)$. Najviše prosječne vrijednosti u CCII 
Tablica 1. Rezultati deskriptivne statističke analize za primijenjene varijable u istraživanju

\begin{tabular}{lrrrrrrc}
\hline Varijable & $\mathrm{k}$ & $\mathrm{N}$ & $\mathrm{Min}$ & $\mathrm{Max}$ & $\mathrm{M}$ & $\mathrm{SD}$ & $\begin{array}{c}\text { Cronbach } \\
\text { alpha }\end{array}$ \\
\hline 1. D-92 & 22 & 210 & 35 & 88 & 66,65 & 9,70 & 0,89 \\
2. Kog- z & & 210 & $-2,40$ & 2,68 & 0,00 & 0,10 & \\
3. CCII-FFA & 8 & 210 & 2 & 16 & 13,15 & 2,37 & $\mathbf{0 , 6 7}$ \\
4. CCII-PHO & 8 & 210 & 3 & 16 & 10,75 & 3,11 & $\mathbf{0 , 6 2}$ \\
5. CCII-OBS & 8 & 210 & 2 & 14 & 9,50 & 2,53 & $\mathbf{0 , 3 7}$ \\
6. CCII-SOM & 8 & 210 & 4 & 16 & 13,18 & 2,55 & $\mathbf{0 , 5 3}$ \\
7. CCII-DEP & 8 & 210 & 4 & 16 & 11,94 & 2,53 & $\mathbf{0 , 4 5}$ \\
8. CCII-HYS & 8 & 210 & 0 & 14 & 4,21 & 2,26 & $\mathbf{0 , 3 1}$ \\
9. CCII- $\Sigma$ & 48 & 210 & 28 & 83 & 63,95 & 10,13 & $\mathbf{0 , 7 8}$ \\
\hline
\end{tabular}

Napomena . $\mathrm{k}=$ broj zadataka $\mathrm{u}$ testovima; $\mathrm{N}=$ broj ispitanika; $\mathrm{Min}=$ minimalni rezultati; $\mathrm{Max}=$ maksimalni rezultat; $\mathrm{M}=$ aritmetičke sredine; $\mathrm{SD}=$ standardne devijacije rezultata $\mathrm{u}$ testovima, D-92 skala depresije, Kog-z standardizirani rezultat u primijenjenim kognitivnim testovima, CCII Crown Crispov indeks iskustava, CCII-FFA - subskala anksioznosti, CCII-PHO - subskala fobičnosti, CCII-OBS - subskala opsesivnosti, CCII-DEP - subskala depresivnosti i CCII-HYS - subskala histerije, CCII- $\Sigma$ ukupan rezultat .

utvrđene su na ljestvicama generalizirane $(M=13,15)$ i somatizirane anksioznosti $(\mathrm{M}=13,18)$

Iz Tablice 2 vidljivo je da je rezultat na D-92 skali depresije u statistički značajnoj, blagoj negativnoj korelaciji s općom mentalnom sposobnosti, te statistički značajnoj, visokoj pozitivnoj korelaciji sa svim ispitanim psihoneurotskim obilježjima

Tablica 2. Interkorelacije svih varijabli u istraživanju

\begin{tabular}{|c|c|c|c|c|c|c|c|c|c|}
\hline & 1 & 2 & 3 & 4 & 5 & 6 & 7 & 8 & 9 \\
\hline 1. Kog.-Z & 1 & & & & & & & & \\
\hline 2. D-92 & $-0,27 * *$ & 1 & & & & & & & \\
\hline 3. CCII-A & $-0,17 * *$ & $0,62 * *$ & 1 & & & & & & \\
\hline 4. CCII-P & $-0,28 * *$ & $0,36 * *$ & $0,40 * *$ & 1 & & & & & \\
\hline 5. CCII-O & 0,11 & $0,29 * *$ & $0,36 * *$ & $0,19 * *$ & 1 & & & & \\
\hline 6. CCII-S & $-0,29 * *$ & $0,55 * *$ & $0,56 * *$ & $0,33 * *$ & $0,20 * *$ & 1 & & & \\
\hline 7. CCII-D & $-0,24 * *$ & $0,62 * *$ & $0,59 * *$ & $0,37 * *$ & $0,29 * *$ & $0,49 * *$ & 1 & & \\
\hline 8. CCII-H & 0,03 & 0,05 & 0,10 & $0,18 * *$ & 0,07 & $-0,07$ & 0,07 & 1 & \\
\hline 9. CCII- $\Sigma$ & $-0,22 * *$ & $0,66 * *$ & $0,77 * *$ & $0,67 * *$ & $0,54 * *$ & $0,65 * *$ & $0,74 * *$ & $0,37 * *$ & 1 \\
\hline
\end{tabular}

Napomena. Kog.- $\mathrm{z}=\mathrm{z}$ vrijednost na testovima opće mentalne sposobnosti, D-92 = rezultat na Skali depresije, CCII = ljestvice psihoneurotskih obilježja u Crown-Crispovu indeksu iskustava: CCII $-\Sigma$ - ukupan rezultat, CCII-FFA -subskala anksioznosti, CCII-PHO - subskala fobičnosti, CCII-OBS subskala opsesivnosti, CCII-DEP - subskala depresivnosti i CCII-HYS - subskala histerije.

$\mathrm{N}=210$.

$* \mathrm{p}<0,05 . * * \mathrm{p}<0,01$. 
na CCII. Izuzetak je izostanak povezanosti depresivnosti s histeričnim reakcijama te niska korelacija s rezultatom na ljestvici opsesivnosti. Postoji blaga negativna korelacija s općom intelektualnom sposobnosti na CCII ljestvicama generalizirane i somatizirane anksioznosti, fobičnosti i depresivnosti. Za ljestvice opsesivnosti i histeričnosti nije utvrđena povezanost s rezultatima na testovima opće intelektualne sposobnosti.

U Tablici 2 prikazana je visina povezanosti skale depresije D-92 i CCII subskale depresije - D. Dobivena je visoka razina konvergencije $(r=0,62)$ što je rezultat koji označava da ljestvice vrlo vjerojatno mjere isti konstrukt. Međutim, uvidom u Tablicu 2 ista razina korelacije dobivena je između depresivnosti i generalizirane (D92 i CCII-FFA $r=0,62)$ i somatizirane anksioznosti (D-92 i CCII-SOM r $=0,55$ ). Varijabilitet rezultata nešto je veći za muške ispitanike i nešto su niže vrijednosti aritmetičkih sredina, osobito u grupama depresivnih i anksioznih poremećaja.

Pregledom rezultata u Tablici 4 prikazana visina aritmetičkih sredina upućuje na razlike u visini izmjerene depresivnosti po spolu. Ženski ispitanici s dijagnosticiranom depresijom imali su nešto više rezultate na D-92 skali nego ženski ispitanici s dijagnosticiranim anksioznim poremećajima i ukupno više rezultate, bez obzira na bolest, od muških ispitanika, dok su muški ispitanici imali višu razinu depresivnosti ako im je dijagnosticiran anksiozni (dominantno PTSP) nego depresivni poremećaj, dok su na ostalim duševnim poremećajima bili izjednačeni. Učinjena je analiza varijance za depresivnost kao zavisnu varijablu, a skupine (depresivni, anksiozni i drugi duševni poremećaji) kao nezavisne varijable. Rezultati u Tablici 4 pokazuju

Tablica 3. Zastupljenost ispitanika prema pojedinim dijagnozama u uzorku

\begin{tabular}{llcc}
\hline Skupina & Šifre dijagnoza prema MKB-10 & Broj & $\%$ \\
\hline Depresivni poremećaji & F 32, F 33, F 34 & 77 & 37 \\
Anksiozni poremećaji & F 40, F 41, F 43.1 & 74 & 35 \\
Ostali duševni poremećaji & F10, F 20 & 59 & 28 \\
\hline
\end{tabular}

Tablica 4. Razlika u obilježju depresivnosti između skupina s različitim bolestima - univarijatna analiza varijance (pairwise comparation)

\begin{tabular}{|c|c|c|c|c|c|c|c|}
\hline \multirow{2}{*}{$\begin{array}{l}\text { Depresija } \\
\text { ukupan } \\
\text { rezultat }\end{array}$} & \multicolumn{2}{|c|}{$\begin{array}{l}\text { Depresivni } \\
\text { poremećaji }\end{array}$} & \multicolumn{2}{|c|}{$\begin{array}{l}\text { Anksiozni } \\
\text { poremećaji }\end{array}$} & \multicolumn{2}{|c|}{$\begin{array}{l}\text { Ostali duševni } \\
\text { poremećaji }\end{array}$} & \multirow[b]{2}{*}{ F omjer } \\
\hline & $\mathrm{M}$ & SD & $\mathrm{M}$ & SD & $\mathrm{M}$ & SD & \\
\hline Muškarci & 65,61 & 11,21 & 63,92 & 11,32 & 66,32 & 8,49 & 1,845 \\
\hline Žene & 69,59 & 7,92 & 67,80 & 6,10 & 69,00 & 5,23 & 0,42 \\
\hline Ukupno & 67,66 & 9,83 & 66,00 & 8,95 & 66,54 & 8,26 & 2,895 \\
\hline
\end{tabular}


da u skupinama ispitanika s dijagnosticiranim depresivnim poremećajem, dijagnosticiranim anksioznim poremećajem i drugim duševnim poremećajima, udaljenost aritmetičkih sredina nije statistički značajna. Intersekcija raspodjele rezultata je vrlo visoka pa ispitanici mogu pripadati u sve tri skupine bolesti.

\section{RASPRAVA}

Svrha ispitivanje bila je provjeriti psihometrijske karakteristike Skala depresije D-92 u postupku procjene radne sposobnosti. Provjerena je osjetljivost, pouzdanost, konvergentna i divergentna valjanost te prognostička valjanost ispitana kao sposobnost D-92 skale da na kliničkom uzorku diferencira ispitanike unutar klinički dijagnosticiranih skupina s depresivnim poremećajima, anksioznim poremećajima te poremećajima iz kruga drugih duševnih bolesti. Deskriptivni rezultati upućuju na zadovoljavajuće pokazatelje osjetljivosti skale da razlikuje osobe prema broju i intenzitetu simptoma depresije u odabranom kliničkom uzorku kada se ispitivanje provodi za procjenu radne sposobnosti. Mjera unutarnje konzistencije upućuje na zadovoljavajuću pouzdanost skale D-92. Visoka korelacija rezultata na D-92 skali sa subskalom depresivnosti u CCII upitniku podržava konvergentnu valjanost skale u smislu valjanog mjerenja definiranog konstrukta. U korist divergentnoj valjanosti ne ide visoka korelacija s mjerom anksioznosti kao i sa subskalom somatizirane anksioznosti. Univarijatna analiza varijance razlika u obilježju depresivnosti između skupina s različitim duševnim poremećajima pokazuje da je intersekcija raspodjele rezultata visoka pa ispitanici mogu pripadati u sve skupine bolesti.

U ovom istraživanju utvrđena je niska negativna povezanost depresivnosti s općom intelektualnom sposobnosti. Konceptualno objašnjenje ovog nalaza možemo naći u definiranju depresije. Naime, prema Kolesarić i Krizmanić (1994), depresija se ne smatra unidimenzionalnim konstruktom, jer depresivnost nije samo promjena doživljaja i ponašanja koja se manifestira na čuvstvenom području već zahvaća i kognitivne procese. Može se očekivati da dolazi do kognitivnih promjena potaknutih depresivnošću (Krizmanić i Kolesarić, 1994). Promjene se mogu očitovati u sadržaju kognitivnih faktora kao što je negativna pristranost u pogledu budućnosti, interpretacija budućih događaja kao sigurnih neuspjeha, smanjenju fleksibilnost mišljenja i kvantitativnom sekundarnom (funkcionalnom) sniženju kognitivnih sposobnosti (Novović i sur., 2011).

U istraživanju su utvrđeni visoki koeficijenti korelacije skale depresije D-92 sa subskalom depresivnosti na indeksu iskustava CCII-DEP, sa skalom anksioznosti CCII-FFA i s ukupnim rezultatom na cijelom upitniku CCII- $\Sigma$ kao mjerom generalnih psihoneurotskih obilježja. Visoka razina povezanosti između skala depresije na oba primijenjena upitnika sugerira visoku konvergentnu valjanost skala $(0,62)$. 
Za usporedbu konvergentna valjanost Beckova upitnika depresivnosti sa Skalom depresije na Millonovu inventaru iznosi $\mathrm{r}=0,74$ i sa Skalom distimije $r=0,71$ (Groth-Marnat, 2003).

Međutim visoka razina povezanosti D-92 skale s ljestvicama anksioznosti na CCII pokazuje da su ispitane depresivne osobe često i anksiozne. Rezultat upućuje na mogući komorbiditet depresivnosti i anksioznosti (Vulić-Prtorić i Macuka, 2004), odnosno na povezanosti i isprepletenost samih poremećaja (Novović i sur., 2005). Visoka komorbidnost ovih sindroma utvrđena je kod odraslih (Ninan i Berger, 2001). Istraživanja sugeriraju da je komorbidnost veća kod djece i adolescenata nego kod odraslih (Garber i Weersing, 2010: Vulić-Prtorić, 2004). Za razliku od odraslih i djece, visoka povezanost depresivnosti i anksioznosti kod starih osoba događa se samo u slučajevima izrazite psihopatologije i teškog oštećenja zdravlja (Lenze i sur., 2001; Ninan i Berger, 2001) ili višestrukih eksternalnih rizičnih faktora (Hajncl i Kurtović, 2006). Slična povezanost dobivena je između Beckove skale depresije i Spielbergerova upitnika anksioznosti na obje subskale - anksioznost kao stanje i anksioznost kao osobina ličnosti (Novy, Nelson, Goodwin i Rowzee, 1993). Novović i sur. (2011) zaključuju da je visoka povezanost skala depresivnosti i anksioznosti više pravilo nego izuzetak i jedan od argumenata zbog kojih neki autori smatraju da su depresivnost i anksioznost manifestacije istog poremećaja.

Postoje teorijski pristupi koji nastoje objasniti učestalost komorbiditeta depresivnosti i anksioznosti. Clark, Watson i Mineka, (1994) predlažu tripartitni model kojim su pokušali objasniti relativno visoku povezanost konstrukata anksioznosti i depresije, koji objašnjava odnos ličnosti i anksioznosti te ličnosti i depresije. Prema ovom modelu negativni afektivitet/neuroticizam pozitivno je povezan i s anksioznosti i s depresijom, dok je pozitivni afektivitet/ekstraverzija negativno povezan s depresijom, ali ne i s anksioznosti. Iacoviello i sur. (2010) istaknuli su nekoliko bitnih obilježja komorbiditeta. Prvo, relativno su česti slučajevi anksioznosti bez depresije, no slučajevi čiste depresije su rijetki. Drugo, longitudinalne studije pokazale su da dijagnoza anksioznosti tipično prethodi dijagnozi depresije (Rohde, Lewinsohn, Seeley i Gau, 2013). Treće, Iacoviello i sur. (2010) utvrdili su da bespomoćnost dovodi do pojave anksioznosti, a time i depresije. Kad se očekivana bespomoćnost pretvori u stvarnu, nastaje sindrom s elementima i depresije i anksioznosti. Napokon, ako se opažena vjerojatnost pojave negativnih događaja pretvori u stvarnost, razvija se osjećaj beznađa (Davison i Neale, 1999). Iz navedenog proizlazi da na temelju rezultata u skali depresije D-92 nije bilo moguće razlikovati ova dva poremećaja dominantno zbog toga što su ispitanici iz skupina u kojima su dijagnosticirani kao depresivni poremećaj i kao anksiozni poremećaj iskazivali smetnje iz kruga anksioznosti i depresivnosti istovremeno. Rezultati istraživanja sugeriraju blagu razliku u visini izmjerene depresivnosti po spolu, po kojima su ženski ispitanici s dijagnosticiranom depresijom imali više rezultate na D-92 nego na ljestvicama za anksiozni poremećaji i ukupno više rezultate, bez obzira na bolest, od muških ispitanika, dok su muški ispitanici imali višu razinu depresivnosti ako im 
je dijagnosticiran anksiozni (dominantno PTSP) nego depresivni poremećaj. Vodeći se dobivenim rezultatom u praktičnom okruženju, psihodijagnostička procjena osoba s dijagnosticiranim depresivnim poremećajem treba uključivati istovremenu primjenu skala depresivnosti i (specifičnih) poremećaja anksioznosti.

Skala D-92 u manjoj mjeri je konvergirala s obilježjima histerije i opsesivnosti nego s obilježjima generalizirane i somatizirane anksioznosti. Dok su tvrdnje na D-92 i kliničkim ljestvicama anksioznosti više izraz psihopatoloških odstupanja prema Crown-Crispovu objašnjenju (Crown i Crisp, 1994), CCII-HYS skala sadrži tvrdnje koje su više pokazatelj histerične ličnosti te, iako su mnogi pacijenti oboljeli od konverzivne histerije imali više rezultate na CCII-HYS, nije ih bilo moguće diferencirati na ovoj skali od ekstraverzije. CCII-OBS također dijelom sadrži pitanja koja se odnose na crte ("Jeste li najsretniji dok radite") koje konceptualno ne moraju biti povezane s depresivnim stanjima, ali i one koja se u većoj mjeri odnose na simptome koji pripadaju zasebnoj kategoriji (predstavljeni pitanjem kao što je “Jeste li primijetili da vam se glupe i nerazumne misli stalno vrte po glavi?"). Ovaj nalaz podržava opravdanost DSM-5 klasifikacije duševnih poremećaja u kojoj su opsesivno-kompulzivni i srodni poremećaji izdvojeni iz anksioznih poremećaja i klasificirani u zasebnu kategoriju.

Univarijatna analiza varijance nije pokazala sposobnost D-92 skale da razlikuje ispitanike po skupinama depresivnog, anksioznog poremećaja i drugih duševnih poremećaja. Objašnjenje ovog nalaza je opisani komorbiditet anksioznosti i depresivnosti. Razlike u rezultatu na skali depresije nisu se očitovale i za druge duševne poremećaje, tj. osobe oboljele od psihotičnih poremećaja u remisiji i alkoholizma $\mathrm{u}$ apstinenciji. Na rezultat je mogao utjecati kriterij odabira ispitanika u ovu skupinu koji su ispitani skalom D-92 jer su u psihijatrijskim nalazima imali obilježja anksioznosti i depresivnosti kao negativne simptome primarne bolesti. Osim toga, valjanost psihijatrijske dijagnoze u ovom ispitivanju nije provjeravana. Kako se radi najčešće o subjektivnoj procjeni dijagnoze nakon provedenog psihijatrijskog intervjua, sama dijagnoza je mogla činiti varijablu pogreške u utvrđivanju utjecaja nezavisne na zavisnu varijablu.

Krizmanić i Kolesarić (1994) navode da instrument za ispitivanje depresivnosti mora biti raznolik kako bi zahvatio što više faceta poremećaja, premda to otežava utvrđivanje pouzdanost mjerenja. Nalaz ovog istraživanja pokazuje da je skala D-92 pouzdan instrument unatoč tome što zahvaća heterogeni konstrukt depresivnosti, tj. zahvaća kognitivne, emocionalne, somatske i bihevioralne kriterije depresivnosti.

Dodatno, rezultati ovog istraživanja potvrđuju vrijednost D-92 upitnika za procjenu težine poremećaja klinički dijagnosticirane skupine u situaciji procjene radne sposobnosti u kojoj ispitanici mogu biti motivirani za dobivanje pozitivne ocjene o invalidnosti. Istraživanja pokazuju da motivirani sudionici mogu prepoznati socijalnu poželjnost čestice i svoj odgovor promijeniti u poželjnom smjeru, neovisno o tome o kakvim je česticama riječ (Galić, Jerneić, Belavić, 2009). Nalaz ovog istraživanja pokazuje da je skala depresije D-92 osjetljiv i pouzdan instrument koji 
se može koristiti za procjenu i razlikovanje intenziteta depresivnosti u situaciji u kojoj su ispitanici motivirani za simulaciju i agravaciju. Naime, autori skale su oblikovanjem i načinom prezentacije pitanja i opisivanjem različitih doživljavanja i ponašanja kao svakodnevnih ljudskih reakcija, smanjili efekte socijalno poželjnog ili/i neiskrenog odgovaranja ispitanika. Dokaz za ovaj zaključak je sukladnost statističkih pokazatelja dobivenih na kliničkom uzorku pacijenata u postupcima liječenja (Krizmanić i Kolesarić, 1994) i kliničkom uzorku u situaciji procjene radne sposobnosti u ovom istraživanju. Razlika između prosječnih rezultata depresivnosti u kliničkom uzorku u kojoj se depresivnost ispitivala u svrhu terapije $(\mathrm{M}=62,62$; $\mathrm{SD}=9,69)$ (Krizmanić i Kolesarić, 1994) i prosječnih rezultata u kliničkom uzorku osoba u situaciji procjene radne sposobnosti u ovom istraživanju $(\mathrm{M}=66,65 ; \mathrm{SD}=$ $9,70)$ nije bila statistički značajna $(t=0,29 ; p>0,05)$.

Dodatna je vrijednost istraživanja nalaz o nižoj povezanosti depresivnosti na skali D -92 s rezultatom na skali za utvrđivanje visine opsesivno-kompulzivnog poremećaja. Naime, niža razina povezanosti ide u prilog opravdanju odvajanja kategorija anksioznosti od opsesivno-kompulzivnog poremećaja, kako je to učinjeno u DSM-5 (APA, 2014), dok je u DSM-IV klasifikaciji duševnih poremećaja (APA, 1996) opsesivno-kompulzivni poremećaj uvršten u kategoriju anksioznih poremećaja. Ispitivanje ovih odnosa i njihovo obrazloženje moglo bi biti predmet budućih istraživanja. Osim toga u budućim istraživanjima predlaže se provjera D-92 skale i na drugim skupinama bolesti kao i samostalni doprinos D-92 skale u bateriji instrumenata za provjeru valjanosti odluka o radnoj sposobnosti osoba s depresivnim poremećajem.

\section{ZAKLJUČAK}

Najvažniji faktor u situaciji procjene radne sposobnosti je opseg kojim je instrument koristan da razlikuje ispitanike po ispitanom obilježju koje djeluje na sposobnost radnog funkcioniranja neke osobe. U ovom je istraživanju ispitano je li Skala depresije D-92 koristan instrument za razlikovanje osobe s depresivnim poremećajem u kliničkom uzorku u specifičnoj situaciji procjene radne sposobnosti te može li ista skala razlikovati osobe s anksioznim, depresivnim i drugim duševnim poremećajem.

Može se zaključiti da čestice skale D-92 pouzdano i osjetljivo mjere depresivnost na kliničkom uzorku u specifičnom kontekstu procjene radne sposobnosti. Skala - 92 pokazala je visoku konstruktnu valjanost s drugom primijenjenom skalom depresivnosti. Istraživanje upućuje na dodatnu vrijednost ove skale, u odnosu na druge upitnike depresivnosti, jer je manje osjetljiva na socijalno poželjno odgovaranje u situaciji procjene radne sposobnosti. Primjenom D-92 skale utvrđena je nedovoljna diskriminativna valjanost u odnosu na anksioznost, što se objašnjava visokom povezanosti i isprepletenosti samih poremećaja. Nisu utvrđene statistički 
značajne razlike prosječnih vrijednosti i varijabiliteta rezultata u uzorcima ispitanika s dijagnosticiranim depresivnim, anksioznim i drugim psihičkim poremećajima. Na rezultat je osim obilježja skale D-92 utjecao i kriterij odabira ispitanika u skupine bolesti, kao i valjanost psihijatrijske dijagnoze povezana s poteškoćama klasifikacije anksioznosti i depresivnosti koji se sve više tumače kao različite manifestacije istog, a ne dva neovisna poremećaja.

\section{LITERATURA}

Američka psihijatrijska udruga (1996). Dijagnostički i statistički priručnik za duševne poremećaje, Četvrto izdanje, Međunarodna verzija. Jastrebarsko: Naklada Slap.

Američka psihijatrijska udruga (2014). Dijagnostički i statistički priručnik za duševne poremećaje, peto izdanje. Jastrebarsko: Naklada Slap.

Beck, A. T. (1970). Cognitive therapy: Nature and relation to behavior therapy. Behavior Therapy, 1, 184-200.

Beck, A. T., Steer, R. A. i Brown, G. K. (1996). Beck Depression Inventory-Second Edition Manual. San Antonio: The Psychological Corporation.

Beck, A. T., Steer, R. A. i Brown, G. K. (2009). BDI-II - Beckov inventar depresije. Priručnik. Jastrebarsko: Naklada Slap.

Beck, J. S., Beck, A. T., Jolly J. B. i Steer, R. A. (2011). Beckov inventar za djecu i adolescente. Priručnik. Jastrebarsko: Naklada Slap.

Butcher, J. i Williams, C. L. (1999). Bitne odrednice interpretacija MMPI-2 i MMPI-A inventara. Jastrebarsko: Naklada Slap.

Clark, L.A., Watson, D. i Mineka, S. (1994). Temperament, personality, and the mood and anxiety disorders. Journal of Abnormal Psychology, 103(1), 103-116.

Cramer, A. O. J., Waldorp, L. J., van der Maas, H. L. J. i Borsboom, D. (2010). Comorbidity: A network perspective. Behavioral and Brain Sciences, 33(2/3), 137-193.

Crown. S., Crisp A. H. (1994). Priručnik za Crown-Crispov indeks iskustava. Jastrebarsko: Naklada Slap.

Davison, G. C. i Neale, J. M. (1999). Psihologija abnormalnog doživljavanja i ponašanja. Jastrebarsko: Naklada Slap.

Feöcze, V. (1994). Utvrđivanje osnovnih metrijskih karakteristika upitnika depresivnosti D -92 na uzorku studenata tri zagrebačka fakulteta. Diplomski rad. Odsjek za psihologiju, Filozofski fakultet, Zagreb.

Galić, Z., Jerneić, Ž. i Belavić, M. (2009). O svecima i superherojima: Provjera Paulhusova modela socijalne poželjnosti. Društvena istraživanja Zagreb, 6(104), 977-997.

Garber, J. i Weersing, V. R. (2010). Comorbidity of anxiety and depression in youth: Implications for treatment and prevention. Journal of Clinical Psychology, 17(4), 293-306.

Groth-Marnat, G. (2003). Handbook of psychological assessment. New Jersey: John Wiley and sons.

Hajncl, Lj. i Kurtović, A. (2006). Stavovi prema službama za mentalno zdravlje osoba starije životne dobi. 14 GKHP Vodice, HPD, DP Šibenik: Knjiga sažetaka str., 34. 
Hamilton, M. (1960). A rating scale for depression. Journal of Neurology, Neurosurgery and Psychiatry, 23, 56-62.

Hathaway, S. R. i McKinley, J. C. (1943). The Minnesota Multiphasic Personality Schedule. University of Minnesota Press, Minneapolis.

Hautzinger M. (2009). Depresija - Modeli, dijagnosticiranje, psihoterapije, liječenje. 2 izdanje. Jastrebarsko: Naklada Slap.

Iacoviello, B. M., Lauren B., Alloy, L. B., Abramson, L, Y., Jimmy Y. i Choi, B.A. (2010). The Early Course of Depression: A Longitudinal Investigation of Prodromal Symptoms and Their Relation to the Symptomatic Course of Depressive Episodes. Journal of Abnormal Psychology, 119(3), 459-467.

Kaplan, H. I. i Sadock B. J. (1998). Priručnik kliničke psihijatrije. Jastrebarsko: Naklada Slap. Prijevod drugog izdanja.

Kovacs, M. (1981). Rating scales to assess depression in school aged children. Acta Paedopsychiatrica, 46, 305-315.

Krizmanić, M. i Kolesarić, V. (1994). Priručnik za primjenu Skale depresije D-92. Jastrebarsko: Naklada Slap.

Lenze, E. J., Mulsant, B. H., Shear, M. K., Alexopoulos, G. S., Frank, E. i Reynolds, C. F. (2001). Comorbidity of depression and anxiety disorders in later life. Journal of Depression and Anxiety, 14(2), 86-93.

Marinović, L. i Vulić-Prtorić, A. (2000). Usporedba dviju skala depresivnosti s obzirom na neke psihometrijske karakteristike. Radovi Filozofskog fakulteta u Zadru-RFFZD, 39(16), 155-177.

Matešić, K. (1994). Podaci o Purdue neverbalnom testu (PNT). Jastrebarsko: Naklada Slap.

Meehl, P. F. (1962). Schizotaxia, schizotypy, schizophrenia. American Psychologist, 17(12), 827-838.

Millon, T. (1977). The Millon inventories: Clinical and personality assessment. New York: Guilford Press.

Momirović, A. i Sučević, Đ. (2004). Priručnik za Kognitivni neverbalni test (KNT). Jastrebarsko: Naklada Slap.

Ninan, P.T. i Berger, J. (2001). Symptomatic and syndromal anxiety and depression. Journal of Depression and Anxiety, 14(2), 79-85.

Novović, Z., Gavrilov, V., Tovilović, S., i Biro, M. (2005). Neke karakteristike Bekove skale beznadežnosti. Psihologija, 38(1), 77-92.

Novović, Z., Mihić, Lj., Tovilović, S., Jovanović, V. i Biro, M. (2011). Psihometrijske karakteristike Bekove skale depresivnosti na uzorku studenata u Srbiji. Psihologija, 44(3), 225-243.

Novy, D. M., Nelson, D. V., Goodwin, J. i Rowzee, R. D. (1993). Psychometric comparability of the State-Trait anxiety inventory for different ethnic subpopulations. Psychological Assessment, 5(3), 343-349.

Proroković, A., Zelić, S., Vulić-Prtorić, A. (2004). Upitnik automatskih misli-ATQ. Zbirka psihologijskih skala i upitnika 1, 9-84. Zadar: Sveučilište u Zadru.

Raven, J. C., Court, J. H. i Raven, J. (1994). Priručnik za Ravenove progresivne matrice $i$ ljestvice rječnika. Jastrebarsko: Naklada Slap. 
Rohde, P., Lewinsohn, P. M., Klein, D. N., Seeley, J. R. i Gau, J. M. (2013). Key characteristics of major depressive disorder occurring in childhood, adolescence, emerging adulthood, adulthood. Clinical Psychological Science, 1(1), 10.

Rush A.J., Giles D.E., Schlesser, M. A., Fulton C. L., Weissenburger J. i Burns C. (1986). The Inventory for Depressive Symptomatology (IDS): Preliminary findings. Psychiatry Research, 18, 65-87.

Tomica, D. (2009). Povezanost pokazatelja depresivnosti izmjerene Beckovom ljestvicom depresije II i skalom depresije D-92. Diplomski rad, Sveučilište JJ Strossmayera u Osijeku, Filozofski fakultet Osijek.

Vulić-Prtorić, A. (2004). Depresivnost u djece i adolescenata. Jastrebarsko: Naklada Slap.

Vulić-Prtorić, A. (2003). Skala depresivnosti za djecu i adolescente - SDD. Jastrebarsko: Naklada Slap.

Vulić-Prtorić, A. i Macuka, L. (2004). Anksioznost i depresivnost - fenomenologija komorbidnosti. Suvremena psihologija, 7(1), 45-64.

Waller, N. G. i Meehl, P. E. (1998). Multivariate taxometric procedures: Distinguishing types from continua. Newbury Park, CA: Sage.

Yesavage, J. A., Brink, T. L., Rose, T. L., Lum, O., Huang, V., Adey, M. i Ottoheirer, V. (1982). Development and validation of a geriatric depression screening scale: A preliminary report. Journal of Psychiatric Research, 17(1), 37-49.

Zung, W.W. (1965). A self-rating depression scale. Archive of General Psychiatry, 12, 63-70.

\title{
MEASUREMENT OF DEPRESSION IN WORKING CAPABILITY ASSESSMENT: PSYHOMETRIC CHARACTERISTICS OF THE D-92 DEPRESSION SCALE
}

\begin{abstract}
Summary
The D-92 Scale of Depression (Krizmanić and Kolesarić, 1994) is the original Croatian psychological instrument for the measurement of the intensity of depression symptoms in the clinical and general adult population. Relying on Beck's theory of emerging and maintaining symptoms of depression, the scale includes issues that question the attitude of the respondent toward himself, toward other people and toward the future. The scale is intended to estimate the severity of the disorder of a clinically diagnosed group. In this paper, discrimination, reliability and validity of D-92 scales and the ability to differentiate subjects within clinically diagnosed groups with depressive disorder, anxiety disorders and other mental disorders, have been tested. The study was conducted on a sample of 210 clinically diagnosed subjects (127 males and 93 females) with depressive, anxiety and other mental disorders. Subjects completed the cognitive ability test, the Crown-Crisp Experiential Index and the D-92 depression scale. Descriptive indicators show very good sensitivity of the scale in differentiating persons according to the number and intensity of the symptoms of depression
\end{abstract}


in the selected clinical sample in the workability assessment situation $(M=66,65$, $\mathrm{SD}=9,70)$. Internal consistency $(\alpha=0,89)$ showed high reliability of the D-92scale. Convergent validity is supported by a high correlation with the depression subscale in CCII Experiential Index $(r=0,62)$. Divergent validity was not confirmed, results showed high correlations with a measure of free-floating anxiety $(r=0,62)$ and somatic concomitants of anxiety $(r=0,55)$. Univariate analysis of variance shows in the character of depression between groups with different diseases indicates that the intersection of the distribution of results is high and the respondents can belong to all groups of the disease.

Keywords: work ability assessment, scale of depression D-92, psychometric characteristics 
